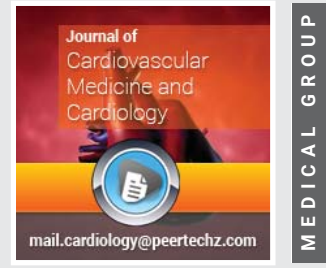

\title{
Mesenchymal Stem Cells and Cardiovascular Diseases
}

\section{Ayapati Gautam Mehdi ${ }^{1,4}$, Vikram Aiman Ayapati ${ }^{1}$, Avinash B} A. A. Khan7, Nirmal Kumar Lohiya ${ }^{2}$, Vijay Lakshmi ${ }^{6}$, Dharma Rakshak Ayapati ${ }^{3}$, Roya Rozati ${ }^{1,5 *}$

${ }^{1}$ MHRT Hospital and Research Centre, 8-2-120/86/1A Road No \#3, Banjarahills,, Hyderabad-500 034 ,

Telangana, India

${ }^{2}$ Department of Zoology, University of Rajasthan, Jaipur, Rajasthan, India

${ }^{3}$ Apollo Hospital, Secunderabad, Telangana, India

${ }^{4}$ Jaipur National University, Jaipur-302 004, Rajasthan, India

${ }^{5}$ Professor and Unit chief II, Department of Obstetrics and Gynecology, Shadan Institute of Medical Sciences, Hyderabad, Telangana, India

${ }^{6}$ Department of Obstetrics and Gynecology, Bhaskar Medical College, Hyderabad, Telangana, India

${ }^{7}$ Central Research Laboratory, CLRD, Hyderabad, Telangana, India
Received: 20 April, 2020

Accepted: 27 April, 2020

Published: 29 April, 2020

*Corresponding author: Dr. Roya Rozati, Professor and Unit chief II, Department of Obstetrics and Gynecology, Shadan Institute of Medical Sciences 8-2-120/86/1A Road No \#3, Banjarahills, Hyderabad-500 034, Hyderabad, Telangana, India, Tel: 040-23552525.

E-mail:drroyarozati@gmail.com

https://www.peertechz.com

\section{Check for updates}

\section{Abstract}

Stem cell therapy has begun as a promising and novel approach for the treatment of various diseases. Stem cell therapy involves the identification of correct cells, area of transplantation. Transplantation of functional and healthy stem cells help to renewal of damaged cells and repair injured tissue. Stem cell isolated from bone marrow were the first cell type used in preclinical and clinical investigations for the have been extended to the use of various populations of stem cells. But there are very few studies which show the roles of stem cells in cardiovascular disease. Cardiovascular Disease (CVD) constitutes the most important cause of mortality and morbidity worldwide. CVD represents a group of disorders connected with the defeat of cardiac function. In spite of significant advances in the understanding of the pathophysiological mechanisms of the disease, the problem of cardiac tissue loss has not yet been addressed. Only few therapeutic approaches suggest through tissue repair and regeneration. The most of treatment options aim to control the scar formation and adverse remodeling, while improving myocardial function. Of all the existing therapeutic approaches, the problem of cardiac tissue loss is addressed uniquely by heart transplantation. This review addresses the present state of research as regards stem cell therapy for CVD.

\section{Introduction}

Cardio vascular disease (CVD) is the foremostreason of morbidity and mortality. Progression and development of myocardial infarction and is a primarycause for heart failure. Present therapeutically strategies to treat infracted heart and consequent heart failure comprise drugs ( $\beta$-blockers and angiotensin, aspirin converting enzyme inhibitors), thrombolytic therapy, angioplasty, heart transplantation and ventricular assist devices. The relative incidence and death occurring due to MI aresignificantly increasing.As a result there is a need to identifynovel therapeutic strategies. MI, in general considered as a heart attack, which occurs due to reduced blood flow or stopping of blood flow to a portion of heartthat results in heart muscle damage. The most common form of CVD is the myocardial infarction [1]. It is responsible for over $15 \%$ of mortality each year, among the vast majority of people suffering from non ST-segment elevation myocardial infarction (NSTEMI) than ST-segment elevation myocardial infarction (STEMI). The prevalence of myocardial infarction (MI) is higher in men in all age-specific groups than women [1].

More than $30 \%$ of individuals show atypical symptoms [2]. In women's chest pain may not be noticed but show symptoms of arm pain, neck pain, or feel tired [3]. In women above 75 years, $5 \%$ are affected with MI without any history of symptoms [4]. MI might lead to an irregular heartbeat, heart failure, or cardiac arrest. Based on World Health Organization (WHO), CVD are the major killers of people in recent times, 
and it's basically because heart cannot renovate itself properly. Even if a person survives after the initial heart attack event, scar tissue renders the heart less effective at pumping blood and more likely to suffer future heart attacks.

In coming decades, in western world degeneration of cardiac tissue will be a key threat for mortality. Thus MI is going to be a health issue in coming years. Cardiac damage is linked with permanent loss and dysfunction of cardiomyocytes [5]. Currently, coronary artery bypass grafting, intervention, and drugs are used to partially recover from myocardial ischemia, yet these treatments are not enough to restore tissue damage occurred due to MI. Local decrease in the cardiocytes number in infracted region resulted from increased oxidative stress in inflammatory microenvironment, scar tissue formation, tissue fibrosis and cardiac remodelling are the major reasons for higher rates of mortality due to heart failure after MI. Hence researchers and clinicians have started to find out newer therapies in treating heart failure resulted due to MI.

Coronary stent implantation, thrombolysis, coronary artery bypass grafting and pharmacotherapy are in current clinical use for treating MI to further enhance patients' survival. However these treatments couldn't able to meet up the fundamental requirements need to repair the injured heart and failed to restore the heart function. In these condition advances in regenerative medicine using stem cells has raised a scope for treating MI. Recently stem cell transplantation has showed a noteworthy evolution in preclinical as well as in clinical studies [6].

The regenerative ability of the adult mammalian heart is very partial, and this subsidizes to the widespread morbidity and mortality associated with CVD $[7,8]$. It has also become progressively outward that adult mammalian hearts do not anchorage endogenous stem cells of any physiological significance that can restore injured myocardium. Despite comprehensive research with numerous cell types over 15 years, stem cell therapy outcomes for cardiac repair have thus far been marginal at best.

Stem cells have long been examined as an answer, but despite their reformative progression in other parts of the body, they are not successful in matters of the heart. Introducing stem cells into the heart may cause difficulties, and it turns out that cardiac stem cells might not even exist. Several other investigators have done so much of research using stem cell "messengers" as an alternative, or converting other heart cells into beating heart cells.

\section{Stem cell and regenerative medicine}

Since 1990s, developmental biologists and embryologists had intensive research on the adult tissue stem cells because they are pluripotent progenitors and present in different tissues.

Stem cells majorly fall under two categories:

1. Pluripotent stem cells: Includes embryonic stem cell (ESC) and induced pluripotent stem cells (iPSCs) and their derivatives.
2. Adult stem cells: Includes hematopoietic stem cells (HSCs) and mesenchymal stem cells (MSCs) [9].

These are mesodermal in origin and are multipotent which resides in adult tissues and embryonic tissues. These are highly immune-privileged, have self-renewal capacity, low tumorigenic in nature and contain immunomodulation properties [10].

It was believed that adult tissue differentiation have the less probability to give rise to different lineages. This perception was swapped by the trans-differentiation concept; the one type of cells can give different lineage to other tissue or cell types [11]. Thus, these cells are believed to be capable for the treatment of various congenital deficiency diseases and regenerate injured tissues [11]. In the 1950s, researchers demonstrated that the bone marrow comprisesof hematopoietic stem cells (HSCs) and mesenchymal stem cells (MSCs) that can generate the cartilage, fat, bone and cells can support the neovascularization [11].

\section{Mesenchymal stem cells}

MSCs compromisean innovative therapeutic tool for the treatment of heart diseases discharging a multitude of bioactive smidgens that ultimately leads to the improvement of tissues at sites of injury [12]. MSCs properties like immunomodulatory capacity, low immunogenicity, prevention of immune rejection, multi lineage differentiation (bone, fat, nerve cells, cartilage), self-renewal capacity puts them on high demand for clinical use in the era of regenerative medicine. MSCs can be obtained from various sources of tissues like fat, bone marrow, synovial membrane and muscle. From all these sources BMSCs are more widely used in clinical applications since their noticeable benefits.

\section{Human Umbilical Cord Blood (UCB) as a source of MSCs}

Human Umbilical Cord Blood (UCB) that make MSCs superior over other sources. Collection of UCB is non-invasive method unlike bone marrow [13,14], they can be efficiently cultured invitro. Collection of UCB does not have much ethical issues [15], cryopreservation of cells does not hinder the proliferation potential of UCB cells making them viable and long lasting [16]. For collecting UCB cells, generally a physician clamps the umbilical cord and makes a prick in the umbilical vein using a syringe and collects the blood into a bag containing nutrients and anticoagulants. The UCB is cleaned of infectious agents prior to cryopreservation and at last stored in blood banks for future utilization [16]. Harvested UCB cells can be effortlessly proliferated, and can be able to cultured invitro [17]. Additionally, cryopreservation of UCB enhances the quantity of mRNA retroviral receptor in cord blood and increases the ability to transduce retroviral vectors. Further this amphotrophic retroviral receptor appearance increases the efficacy of gene therapy since these receptors are major central targets in transduction of gene of interest [18]. In comparison with bone marrow UCB is considered as a richest source for progenitor cells and hematopoietic stem cells with increased proliferation potential [19]. There are several benefits to derive the stem cells from UCB such as

Citation: Mehdi AG, Ayapati VA, Avinash B, AA Khan, Rozati R, et al. (2020) Mesenchymal Stem Cells and Cardiovascular Diseases. J Cardiovasc Med Cardiol 7(2): 
Human UCB serves as eminent source of stem cells and has a number of significant advantages over other stem cell sources.

First of all, non-invasive collection without any risk for the donor and a real abundance with more than 100 million births annually worldwide make the UCB a readily available source of stem cells.

UCB stem cells, unlike the more controversial embryonic stem cells, do not involve ethical issues.

UCB-MSCs do not develop teratoma when injected into the body.

Upon transplantation, these cells have potency to differentiate into the required cell types to provide the support in adverse conditions.

Although the cellular/tissue regeneration mechanisms of myocardial repair or improvement by transplanted UCB-MSCs has yet to be elucidated.

In recent times, researchers revealed that UCB comprises a smaller proportion of Very Small Embryonic-Like stem cells (VSELs) another form of pluripotent stem cells [20]. Recently, cell therapy has gained much attention as an alternative approach to treat various heart diseases. We are still in search of the optimal cell type for enhanced cardiac repair and regeneration.

A variety of cell types has been identified and utilized as a possible remedy to repair damaged myocardium. Reduced apoptosis has been noticed in case of hematopoetic progenitor cells $[21,22]$. It has been demonstrated that Human amniotic epithelial cells could be able to differentiate into cardiomyocytelike cells after transplantation [23]. Enhanced cardiac function has been documented through the usage of MSCs [24-28], skeletal myoblasts, cardiac progenitor cells, endothelial precursor cells, skeletal muscle cells [29], and resident cardiac stem cells for treating Myocardial Infarction (MI) patients. Studies are being conducted on endothelial progenitor cells (EPCs) to enhance cardiac function in MI patients [30-33]. On the other hand still there is deviation with optimal cell graft intended for clinical applications. MSCs isolated from bone marrow of older patients when cultured in vitro exhibited lack of self-renewal, adhesion, proliferation, and integration into vascular tissue upon transplantation into damaged heart. Currently autologous transplantation is in wide applicability as this therapy circumvents graft versus host immune disease. But this autologous transplantation is not preferable in case of chronically ill and aging populations, where functional SCs number got decreased, restricting the recovery as well as repairing capacity of damaged tissue.

It has been identified that UCB cells inherit the capacity for repairing endothelial cells and muscle cells because of their angiogenic and myogenic properties, representing their suitability in repairing injured myocardium $[9,14]$. So far UCB cells presented extended track record for safety profile in efficient clinical transplantation [16]. Several properties of UCB cells hold up the impression that they can provide better safety and efficacy in transplantation studies.

Several limitations prompts for discovery of most appropriate stem cell sources for utilization in transplantation of MI. Accordingly it was found that UCB cells as the most potential source of stem cells to rule out all these limitations that can be used successfully in transplantation with more benefits. When compared to autologous cells, number of UCB cells obtained is far higher which can be harvested noninvasively, contains the property of self-renewal and can be differentiated into multiple lineages. Most importantly these cells can withstand larger cryopreservation periods, exhibits minimal damage to other proteins and lower risk for losing protein signalling. It is necessary to achieve the survival of transplanted HUCB and its differentiation into endothelial cells or myocytes for promoting left ventricular remodelling. Still for attaining an efficient efficacy and stability of UCB cells for utilization in MI treatment there is a need to carry out many preclinical investigations as well as to reveal the underlying mechanism by which UCB cells help in myocardial repair [34].

\section{Various Studies on Stem cells and CVD}

MSCs are the have become most common cell type of choice that are being used in MI clinical trials (Table 1) [35], because of their immunomodulatory properties, multi differentiation potential, nutritional activity, abundant donor sources and safety $[10,36]$. MSCs shows low expression of MHC II and donot express of MHC class-I making them less immunogenic and will not elicit immune rejection during allogeneic transplantation [36]. Conversely, the therapeutic outcome of MSC transplantation is disappointing.

Huang, et al. 2019 [37], showed that combinatorial delivery of exosomes and stem cells in a sequential manner

Table 1: Clinical trials for the treatment of MI by MSCs transplantation.

\begin{tabular}{|c|c|c|c|}
\hline Phase & Dose $\left(\boldsymbol{*}^{\mathbf{*}}\right)$ & Following up & Study \\
\hline Phase 1/2 & 20 & 12 months & Can et al. 2015 \\
\hline Phase 2 & 150 & 6 months & Schutt et al., 2015 \\
\hline Phase 2 & 100 & 12 months & Florea et al. 2017 \\
\hline Phase 2 & 6 & 18 months & Gao et al. 2015 \\
\hline Phase 1/2 & $180 / 220$ & 24 months & Chullikana et al. 2015 \\
\hline
\end{tabular}

effectively reduces scar size and restores heart function after Acute Myocardial Infarction (AMI). Delivery of exosomes into infracted hearts 30min post (AMI) can significantly reduce inflammatory factors such as IL- 6 and TNF- $\alpha$, increase SDF-1 expression and angiogenesis, and promote stem cell survival in the stressed ischemic microenvironment at day 3 post AMI.

Only 3-10\% of MI patients transplanted with MSCs showed an increase in Left Ventricular Systolic Function (LVSF) [38]. One of the reasons for this failure might be the inability of implanted cells for long term survival. Results showed that only around 3\% of MSCs presence in marginal area of the infarcted 
myocardium after 24 hours of systemic administration, it was even noticed that less than $1 \%$ of MSCs can able to survive for more than a week [9]. Current studies showed that paracrine mechanism plays a major role in success of MSC therapy in treating MI patients and it was even found that it is difficult to differentiate MSCs into cardiomyocytes [39].

BMSCs possess the ability of multidirectional differentiation, low high portability and lesser immunogenicity. All these properties of BMSCs make them as an ideal source of cells for utilization in cardiovascular disease therapies. In additions BMSCs express CXC chemokine receptor 4 (CXCR4) and chemotactic protein stromal cell derived factor 1 (SDF-1) enhances their automatic homing ability on infracted area subsequent to transplantation [40-42], which finally helps in treating of cardiovascular disease.

The sequential events that occur after BMSCs transplantation into ischemic myocardium includes differentiation and fusion of BMSCs to cardiocytes and endothelial cells; paracrine effects associated with release of diverse cytokines like interleukin (IL)-6, platelet-derived growth factor, Vascular Endothelial Growth Factor (VEGF), Hepatocyte Growth Factor (HGF), Insulin-like Growth Factor (IGF), SDF-1 and Fibroblast Growth Factor (FGF) which plays a crucial role in restoring cardiac function. This is followed by mobilization of autologous progenitor cells or cardiac stem cells and promoting their proliferation and differentiation into cardiomyocytes for recovering cardiac function. Further the myocardium is protected by inhibiting inflammatory responses by decreasing the levels of inflammatory cytokines and gene expression. Several studies have shown that BMSCs transplantation in MI enhanced the differentiation of surrounding cardiocytes in infracted area [43,44]. Further these transplanted BMSCs in MI enhanced angiogenesis, inhibited apoptosis, and exhibited anti-fibrotic properties and helped in significant improvement of myocardial repair in MI patients. Joint autologous BMSC therapy and shock wave has showed to be most effective than using in single [45].

Bone marrow stem cells (BMSCs) transplantation has revealed potential for cardiac regeneration [46], since within the microenvironment of the heart they can differentiate into cardiac cells [47-54], without making physical contacts with myocytes [48-53]. There may be probable elucidation is that one or additional influences secreted from myocytes stimulate BMSCs' differentiation into a myocardial phenotype. BMSCs may be provided by coronary artery infusion, and they travel to the site of injury and differentiate into myocardial cells in the damage tissue to progress heart function.

\section{Conclusion}

In summary, the potential usefulness of UCB derived stem cells is can be opted in preclinical settings due to readily available source, multipotent nature, immunologically naive and minimal ethical concerns. The success of this therapeutic strategy in preclinical models will facilitate the production and clinical applicability which has tremendous potential to save millions of lives each year with further understanding. Stem cell based therapeutic approach may represent as an alternative promising strategy heart repair and therapy.

\section{References}

1. Jayaraj JC, Davatyan K, Subramanian SS, Priya J (2018) Epidemiology of Myocardial Infarction. Intech Open. Link: https://bit.ly/3bLrcwf

2. Steg PG, James SK, Atar D, Badano LP, Blömstrom-Lundqvist C, et al. (2012) ESC Guidelines for the management of acute myocardial infarction in patients presenting with S-Tsegment elevation. Eur Heart J 33: 2569-2619. Link: https://bit.ly/3cUyq0U

3. Coventry LL, Finn J, Bremner AP (2011) Sex difference in symptom presentation in acute myocardial infarction: a systematic review and metaanalysis. Heart Lung 40: 477-491. Link: https://bit.ly/3f01xlc

4. Valensi P, Lorgis L, Cottin Y (2011) Prevalence, incidence, predictive factors and prognosis of silent myocardial infarction: a review of the literature. Arch Cardiovasc Dis 104: 178-188. Link: https://bit.ly/35cWhGL

5. Eltyeb A, Tomasz S, César GSL, Carvalho KAT, Gallo P, et al. (2011) Stem cell therapy in heart diseases: a review of selected new perspectives, practica considerations and clinical applications. Curr Cardiol Rev 7: 201-212. Link: https://bit.ly/2VG3NGS

6. Ji ST, Kim H, Yun J, Chung JS, Kwon SM (2017) Promising therapeutic strategies for mesenchymal stem cell-based cardiovascular regeneration: from cell priming to tissue engineering. Stem Cells Int 2017: 3945403: Link: https://bit.ly/3aLcQKK

7. Xin M, Olson EN, Bassel-Duby R (2013) Mending broken hearts: Cardiac development as a basis for adult heart regeneration and repair. Nat Rev Mol Cell Biol 14: 529-541. Link: https://bit.ly/3aCWJ20

8. Bergmann O, Bhardwaj RD, Bernard S, Zdunek S, Barnabé-Heider F, et al (2009) Evidence for cardiomyocyte renewal in humans. Science 324: 98-102. Link: https://bit.ly/35mJTnH

9. Vizoso FN, Eiro S, Cid JS, Perez-Fernandez R (2017) Mesenchymal stem cell secretome: toward cell-free therapeutic strategies in regenerative medicine. International Journal of Molecular Sciences 18: 1852. Link: https://bit.ly/3cUQ4I8

10. Sanina C, Hare JM (2015) Mesenchymal stem cells as a biological drug for heart disease: where are we with cardiac cellbased therapy?. Circ Res 117: 229-233. Link: https://bit.ly/3eX9dom

11. Sell SP (2004) Stem cell handbook, Humana Press Inc, New Jersey. Link: https://bit.ly/3eWLnZT

12. Saito K, Kuang J, Lin C, Chiu R (2003) Transcoronary implantation of bone marrow stromal cells ameliorates cardiac function after myocardial infarction. J Thorac Cardio vasc Surg 126: 114-123. Link: https://bit.ly/2SdSF1M

13. Smith AR, Wagner JE (2009) Alternative haematopoietic stem cell sources fo transplantation: place of umbilical cord blood. Br J Haematol 147: 246-261. Link: https://bit.ly/2VLkoJw

14. Zhong XY, Zhang B, Asadollahi R, Low SH, Holzgreve W (2010) Umbilica cord blood stem cells: what to expect. Ann N Y Acad Sci 1205: 17-22. Link: https://bit.ly/3bN4luA

15. Newman MB, Davis CD, Borlongan CV, Emerich D, Sanberg PR (2004) Transplantation of human umbilical cord blood cells in the repair of CNS diseases. Expert Opin Biol Ther 4: 121-130. Link: https://bit.ly/3bMjYrJ

16. Bronxmeyer HE, Srour EF, Hangoc G, Cooper S, Anderson SA, et al. (2003) High-efficiency recovery of functional hematopoetic progenitor and stem cells from human cord blood cryopreserved for 15 years. Proc Natl AcadSci U S A 100: 645-650. Link: https://bit.ly/2SdmzmU 
17. Gluckman E, Ruggeri A, Volt F, Cunha R, Boudjedir K, et al. (2011) Milestones in umbilical cord blood transplantation. $\mathrm{Br} \mathrm{J}$ Haematol 154: 441-447. Link: https://bit.ly/3eVxTOB

18. Orlic D, Girard LJ, Anderson SM, Do BK, Seidel NE, et al. (1997) Transduction efficiency of cell lines and hematopoietic stem cells correlates with retrovirus receptor mRNA levels. Stem Cells 15: 23-29. Link: https://bit.ly/3bIWpzX

19. Hows JM, Marsh JC, Bradley BA, Luft T, Coutinho L, et al. (1992) Human cord blood: a source of transplantable stem cells? Bone Marrow Transplant 9: 105108. Link: https://bit.ly/2KFJ2oq

20. Ratajczak MZ, Suszynska M, Pedziwiatr D, Mierzejewska K, Greco NJ (2012) Umbilical cord bloodderived very small embryonic like stem cells (VSELs) as a source of pluripotent stem cells for regenerative medicine. Pediatr Endocrino Rev 9: 639-643. Link: https://bit.ly/2W219dq

21. Zeng H, Li I, Chen LX (2012) Overexpression of angiopoietin-1 increases CD133+/c-kit+ cells and reduces myocardial apoptosis in $\mathrm{db} / \mathrm{db}$ mouse infarcted hearts. PLoS One 7: e35905. Link: https://bit.ly/2SdDeqa

22. Orlic D, Kajstura J, Chimenti S, Jakoniuk I, Anderson SM, et al. (2001) Bone marrow cells regenerate infarcted myocardium. Nature 410: 701-705. Link https://bit.ly/2KEuQMz

23. Fang $\mathrm{CH}$, Jin J, Joe JH, Song YS, So BI, et al. (2012) In Vivo Differentiation of Human Amniotic Epithelial Cells into Cardiomyocyte-Like Cells and Cell Transplantation Effect on Myocardial Infarction in Rats: Comparison with Cord Blood and Adipose Tissue-Derived Mesenchymal Stem Cells. Cell Transplant 21: 1687-1696. Link: https://bit.ly/2W4ANYj

24. MacDonald DJ, Luo J, Saito T, Duong M, Bernier PL, et al. (2005) Persistence of marrow stromal cells implanted into acutely infarcted myocardium: observations in a xenotransplant model. J Thorac Cardiovasc Surg 130: 11141121. Link: https://bit.ly/3cRzYJ9

25. Amado LC, Saliaris AP, Schuleri KH, St John M, Xie JS, et al. (2005) Cardiac repair with intramyocardial injection of allogeneic mesenchymal stem cells after myocardial infarction. Proc Natl Acad Sci U S A 102: 11474-11479. Link: https://bit.ly/2W3XxaR

26. Gaebel R, Furlani D, Sorg H, Polchow B, Frank J, et al. (2011) Cell origin of human mesenchymal stem cells determines a different healing performance in cardiac regeneration. PLoS One 6: e15652. Link: https://bit.ly/2xUILMR

27. Hassan F, Meduru S, Taguchi K, Kuppusamy K, Mostafa M, et al. (2012) Carvedilol enhances mesenchymal stem cell therapy for myocardial infarction via inhibition of caspase-3 expression. J Pharmacol ExpTher 343: 62-71. Link: Link: https://bit.ly/2VJnu0s

28. Cerrada I, Ruiz-Sarui A, Carrerro R, Trigueros C, Dorronsoro A, et al (2012) Hypoxia-inducible factor 1 alpha contributes to cardiac healing in mesenchymalstem cells mediated cardiac repair. Stem Cells Dev 22: 501-511. Link: https://bit.ly/3bLi360

29. Wang JS, Kovanecz I, Vernet D, Nolazco G, Kopchok GE, et al. (2012) Effects of sildenafil and/or muscle derived stem cells on myocardial infarction. J Trans Med 10: 159. Link: https://bit.ly/2VJIG6

30. Dib N, Michler RE, Pagani FD, Wright S, Kereiakes DJ, et al. (2005) Safety and feasibility of autologous myoblast transplantation in patients with ischemic cardiomyopathy: four-year follow-up. Circulation 112: 748-1755. Link: https://bit.ly/3bLfotl

31. Povsic TJ, O'Connor CM, Henry T, Taussig A, Kereiakes DJ, et al. (2011) A double-blind, randomized, controlled, multicenter study to assess the safety and cardiovascular effects of skeletal myoblast implantation by catheter delivery in patients with chronic heart failure after myocardial infarction. Am Heart J 162: 654-662. Link: https://bit.ly/2VIq1rF

32. Konoplyannikov M, Haider K, Lai VK, Ahmed RP, Jinag S, et al. (2012) Activation of diverse signaling pathways by ex-vivo delivery of multiple cytokines for myocardial repair. Stem Cells Dev 22: 204-215. Link: https://bit.ly/2VH3g7B
33. Von WR, Blumenthal B, Heilmann C, Golsong P, Poppe A, et al. (2012) Scaffoldbased transplantation of vascular endothelial growth factor-overexpressing stem cells leads to neovascularization in ischemic myocardium but did not show a functional regenerative effect. ASAIO J 58: 268-274. Link: https://bit.ly/3aKYvyb

34. Mozid AM, Arnous S, Sammut EC, Mathur A (2011) Stem cell therapy for heart diseases. Br Med Bull 98: 143-159. Link:

35. Lee S, Choi E, Cha MJ, Hwang KC (2015) Cell adhesion and long-term survival of transplanted mesenchymal stem cells: a prerequisite for cell therapy. Oxid Med Cell Longev 2015: 632902. Link: https://bit.ly/2W5yBQf

36. Miao C, Lei M, Hu W, Han S, Wang Q (2017) A brief review: the therapeutic potential of bone marrow mesenchymal stem cells in myocardial infarction. Stem Cell Res Ther 8: 242. Link: https://bit.ly/2Ye2Irh

37. Huang P, Wang LI, Li Q, Xu J, Xu J, et al. (2019) Combinatorial treatment of acute myocardial infarction using stem cells and their derived exosomes resulted in improved heart performance. Stem Cell Res Ther 10: 300. Link: https://bit.ly/2xUnjXb

38. Liu B, Duan CY, Luo CF, Ou CW, Sun K, et al. (2014) Effectiveness and safety of selected bone marrow stem cells on left ventricular function in patients with acute myocardial infarction: a meta-analysis of randomized controlled trials. Int J Cardiol 177: 764-770. Link: https://bit.ly/2SeX1Wk

39. Maguire G (2014) Stem cell therapy without the cells. Commun Integr Biol 6 : e26631.

40. Wu Y, Zhao RC (2012) The role of chemokines in mesenchymal stem cell homing to myocardium. Stem Cell Rev Rep 8: 243-250. Link: https://bit. ly/2KGF7Yo

41. Tong J, Ding J, Shen X, Chen L, Bian Y, et al. (2013) Mesenchymal stem cell transplantation enhancement in myocardial infarction rat model unde ultrasound combined with nitric oxide microbubbles. PLoS One 8: e80186. Link: https://bit.ly/2KFRPXn

42. Won YW, Patel AN, Bull DA (2014) Cell surface engineering to enhance mesenchymal stem cell migration toward an SDF-1 gradient. Biomaterials 35 5627-5635. Link: https://bit.ly/2y8MpkW

43. Williams AR, Hatzistergos KE, Addicott B, McCall F, Carvalho D, et al. (2013) Enhanced effect of combining human cardiac stem cells and bone marrow mesenchymal stem cells to reduce infarct size and to restore cardiac function after myocardial infarction. Circulation 127: 213-223. Link: https://bit.ly/2KHGJ46

44. Mao Q, Lin C, Gao J, Liang X, Gao W, et al. (2014) Mesenchymal stem cells overexpressing integrinlinked kinase attenuate left ventricular remodeling and improve cardiac function after myocardial infarction. Mol Cell Biochem 397 203-214. Link: https://bit.ly/3cUUjNA

45. Sheu JJ, Lee FY, Yuen CM, Chen YL, Huang TH, et al. (2015) Combined therapy with shock wave and autologous bone marrow-derived mesenchymal stem cells alleviates left ventricular dysfunction and remodeling through inhibiting inflammatory stimuli, oxidative stress \& enhancing angiogenesis in a swine myocardial infarction model. Int J Cardiol 193: 69-83. Link: https://bit.ly/3aGUV7Z

46. Miyahara Y, Nagaya N, Kataoka M, Yanagwa B, Tanaka K, et al. (2006) Monolayered mesenchymal stem cells repair scarred myocardium after myocardial infarction. Nat Med 459-465. Link: https://bit.ly/2yKLYNP

47. Rangappa S, Entwistle JW, Wechsler AS, Kresh JY (2003) Cardiomyocytemediated contact programs human mesenchymal stem cells to express cardiogenic phenotype. J Thorac Cardiovasc Surg 126: 124-132. Link: https://bit.ly/3cRuMVC

48. Li X, Yu X, Lin Q, Deng C, Shan Z, et al. (2007) Bone marrow mesenchymal stem cells differentiate into functional cardiac phenotypes by cardiac microenvironment. J Mol Cell Cardiol 42: 295-303. Link: https://bit.ly/3bKnty

Citation: Mehdi AG, Ayapati VA, Avinash B, AA Khan, Rozati R, et al. (2020) Mesenchymal Stem Cells and Cardiovascular Diseases. J Cardiovasc Med Cardiol 7(2): 088-093. DOI: https://dx.doi.org/10.17352/2455-2976.000119 
49. Schutt RC, Trachtenberg BH, Cooke JP, Traverse JH, Henry TD, et al. (2015) Bone marrow characteristics associated wi-th changes in infarct size after STEMI: a biorepository evaluation from the CCTRN TIME trial. Circ Res 116 99-107. Link: https://bit.ly/2VG8NeC

50. Gao LR, Chen Y, Zhang NK, Yang XL, Liu H, et al. (2015) Intracoronary infusion of Wharton's jelly-derived mesenchymal stem cells in acute myocardial infarction: double-blind, randomized controlled trial. BMC Med 13: 162. Link: https://bit.ly/3cV6ni8

51. Florea V, Rieger AC, DiFede DL, El-Khorazaty J, Natsumeda M, et al. (2017) Dose comparison study of allogeneic mesenchymal stem cells in patients with ischemic cardiomyopathy (The TRIDENT study). Circ Res 121: 1279-1290. Link: https://bit.ly/3eQIzOq
52. Chullikana A, Majumdar AS, Gottipamula S, Krishnamurthy S, Kumar AS, et al. (2015) Randomized, double-blind , phase I/II study of intravenous allogeneic mesenchymal stromal cells in acute myocardial infarction. Cytotherapy 17: 250-261. Link: https://bit.ly/3cXmLia

53. Can A, Ulus AT, Cinar O, Topal Celikkan F, Simsek E, et al. (2015) Human umbilical cord mesenchymal stromal cell transplantation in myocardial ischemia (HUC-HEART Trial). A study protocol of a phase $1 / 2$, controlled and randomized trial in combination with coronary artery bypass grafting. Stem Cell Rev Rep 11: 752-760. Link: https://bit.ly/2W6EooG

\section{Discover a bigger Impact and Visibility of your article publication with} Peertechz Publications

\section{Highlights}

* Signatory publisher of ORCID

* Signatory Publisher of DORA (San Francisco Declaration on Research Assessment)

* Articles archived in worlds' renowned service providers such as Portico, CNKI, AGRIS, TDNet, Base (Bielefeld University Library), CrossRef, Scilit, J-Gate etc.

* Journals indexed in ICMJE, SHERPA/ROMEO, Google Scholar etc.

* OAI-PMH (Open Archives Initiative Protocol for Metadata Harvesting)

* Dedicated Editorial Board for every journal

* Accurate and rapid peer-review process

* Increased citations of published articles through promotions

* Reduced timeline for article publication

Submit your articles and experience a new surge in publication services (https://www.peertechz.com/submission).

Peertechz journals wishes everlasting success in your every endeavours.

Copyright: (c) 2020 Mehdi AG, et al. This is an open-access article distributed under the terms of the Creative Commons Attribution License, which permits unrestricted use, distribution, and reproduction in any medium, provided the original author and source are credited.

Citation: Mehdi AG, Ayapati VA, Avinash B, AA Khan, Rozati R, et al. (2020) Mesenchymal Stem Cells and Cardiovascular Diseases. J Cardiovasc Med Cardiol 7(2) 088-093. DOI: https://dx.doi.org/10.17352/2455-2976.000119 